\title{
UJI EFEK ANTIINFLAMASI EKSTRAK ETANOL DAUN SIRSAK (Annona muricata Linn.) TERHADAP MENCIT (Mus musculus) JANTAN YANG DIINDUKSI DENGAN KARAGEN
}

\author{
Rahmawati, Safriani Rahman, Mustari \\ Fakultas Farmasi Universitas Muslim Indonesia \\ Email : safriani_rahman@yahoo.com
}

\begin{abstract}
The research about aniinflammatory effect of Sirsak leaves (Annona muricata Linn.) ethanolic extract in male mice (Mus musculus) was conducted, the aim to assay the anti-inflammatory effect of Sirsak leaves done extract based on decrease in oedema volume of foot palm male mice. It was used 15 male mices that evaluated and divided into 5 groups that each group has 3 mices given extract in dose of 0,182 $\mathrm{g} / \mathrm{kgBB}, 0,546 \mathrm{~g} / \mathrm{kgBB}$ and $0,91 \mathrm{~g} / \mathrm{kgBB}$, one group as the compore which administered diclofenac sodium, one negative control group which administered $1 \%$ $\mathrm{Na}$.CMC. induction carried out by injection $1 \% \mathrm{w} / \mathrm{v}$ carrageen $0,05 \mathrm{ml}$ subcutan in the feet palm of mice. One hour later each group administered the teste preparation orally $1 \mathrm{ml} / 30 \mathrm{gBW}$. Group 1 to 3 the series dose of the extract 0,182 $\mathrm{g} / \mathrm{kgBB}, 0,546$ $\mathrm{g} / \mathrm{kgBB}$ and 0,91 $\mathrm{g} / \mathrm{kgBB}$. Group 5 diclofenac sodium suspension. The measurement of oedema volume carried out prior and after administration of the tested preparation $0,30,60$, 90, and 120 minutes. The data correlation between oedema versus time analysed value with use SPSS 20.Result indicated variaties with ethanolic Extract of Sirsak leaves have the effect antiinflamatory at dose 0,182 $\mathrm{g} / \mathrm{kgBB}, 0,546 \mathrm{~g} / \mathrm{kgBB}$, dan $0,91 \mathrm{~g} / \mathrm{kgBB}$ and not differ the reality by Natrium Diklofenak.
\end{abstract}

Keywords : Inflamation, Anona muricata's leaf, Carageen.

\section{PENDAHULUAN}

Pada

umumnya

obat

antiinflamasi mempunyai sejumlah efek samping yang berkaitan dengan penggunaan obat-obat sintetik dan terutama terjadi pada lambung, usus, ginjal, dan fungsi trombosit, maka salah satu cara untuk mengatasinya yakni mencari bahan yang berasal dari alam yang tidak mempunyai efek samping (Rahima, 2011).

Kalangan medis pun kini mulai melirik obat tradisional, terutama herbal. Alasannya logis dan konkret. Alasan pertama, tanaman obat jauh lebih murah. Kedua, mudah diperoleh di sekitar kita, mudah ditanam, dan mudah cara membuat ramuannya. Ketiga, tidak menimbulkan efek 
Uji Efek Antiinflamasi Ekstrak Etanol Daun Sirsak Terhadap Mencit Jantan Yang Diinduksi Dengan Karagen

samping sepanjang digunakan sesuai petunjuk (Santoso, 2008).

Salah satu tanaman obat yang sering digunakan oleh masyarakat untuk mengobati radang atau inflamasi adalah daun sirsak (Annona muricataLinn.). Tanaman ini selain dapat mengobati inflamasi juga berkhasiat pada beberapa jenis kanker. Untuk sirsak sendiri telah diteliti dapat mengobati kanker usus besar, kanker paru-paru, kanker pankreas, kanker prostat dan juga kanker payudara (Farah, 2010).

Beberapa penelitian telah dilakukan pada sirsak yang meliputi uji efektivitas dan identifikasi senyawa ekstrak biji Sirsak (Annona muricata Linn.) yang bersifat bioaktif Insektisida nabati terhadap hama thrips oleh Anggrainy Putri (2010)yang hasil penelitiannya menunjukkan bahwa setiap konsentrasi ekstrak bijisirsak yang diberikan memiliki tingkat toksisitas terhadap hama thrips, yang ditunjukkan dengan nilai LC50 < 1000 mg ekstrak/L air, yaitu 16,9272 mg ekstrak/L air pada pengamatan 120 jam setelah penyemprotan.

Rahmawati Nur Jannah (2010) juga melakukan penelitian mengenai uji efektifitas ekstrak daun sirsak
(Annona muricata L) sebagai pestisida nabati terhadap pengendalian hama tanaman sawi (Brassica juncea L) yang hasilnya menunjukkan bahwa ekstrak daun sirsak memberikan efektifitas sebagai pestisida terhadap hama tanaman sawi.Kemudian kajian daya insektisida biji sirsak (Annonamuricata L.) dan srikaya (Annona squamosa L.) terhadap perkembangan Sitophilus zea mays motschulsky oleh Yuyun Umi Kulsum (1998) yang hasil penelitian menunjukkan bahwa tepung dan ekstrak biji sirsak dan biji srikaya mempunyai daya insektisida terhadap perkembanganSitophilus zeamays.

\section{METODE PENELITIAN}

Jenis penelitian yang digunakan adalah penelitian eksperimental laboratoris.

Alat dan Bahan, Alat dan bahan yang akan digunakan disiapkan sesuai dengan kebutuhan penelitian.

\section{A. Prosedur Penelitian}

\section{Penyiapan Sampel.}

Bahan yang digunakan dalam penelitian adalah Daun Sirsak (Annona muricata Linn) yang berasal dari Desa Mario, Kecamatan Kulo Kabupaten Sidrap. 
Uji Efek Antiinflamasi Ekstrak Etanol Daun Sirsak Terhadap Mencit Jantan Yang Diinduksi Dengan Karagen

2. Pengambilan dan Pengolahan Sampel

Cara pengambilan sampel yaitu daun tua atau muda (daun kelima dari pucuk) dipetik satu per satu secara manual kemudian dipetik pada saat tanaman mengalami reaksi fotosintesis sempurna yaitu pada pukul 09.00-12.00.

Daun yang dikumpulkan dicuci bersih menggunakan air yang mengalir dan dirajang atau dipotong-potong selanjutnya dikeringkan dengan cara diangin-anginkan tanpa terpapar oleh sinar matahari.

\section{Pembuatan Bahan Penelitian}

\section{a. Pembuatan ekstrak etanol}

\section{Daun Sirsak (Annona muricata Linn).}

Sebanyak $200 \quad g$ sampel dimaserasi selama $5 \times 24$ jam dengan etanol 96\% $1000 \mathrm{ml}$ dengan pengadukan beberapa kali, kemudian disaring dan ampasnya direndam kembali dengan cairan penyari yang baru, hasil penyarian yang diperoleh dipekatkan dengan menggunakan rotavapor sampai diperoleh ekstrak etanol pekat, kemudian diuapkan lagi hingga didapatkan ekstrak kental dan ditimbang.

b. Pembuatan

Suspensi Ekstrak Etanol Daun Sirsak (Annona muricata Linn)

Ekstrak etanol daun sirsak yang digunakan adalah dosis 0,182 $\mathrm{g} / \mathrm{KgBB}$, 0,546 $\mathrm{g} / \mathrm{KgBB}$, dan 0,91 $\mathrm{g} / \mathrm{KgBB}$. Cara pembuatan suspense ekstrak etanol daun sirsak dosis 0,182 g/KgBB adalah dengan menimbang 1 gram ekstrak etanol daun sirsak kemudian disuspensikan ke dalam Na.CMC $100 \mathrm{ml}$. Dilakukan hal yang sama untuk pembuatan ekstrak etanol daun sirsak dosis 0,546 $\mathrm{g} / \mathrm{KgBB}$ dan 0,91 g/KgBB dengan menimbang ekstrak masing-masing 3 gram dan 5 gram.

c. Pembuatan Suspensi Karagen 1\% b/v.

Sebanyak 1 gram karagen ditambah larutan $\mathrm{NaCl} 50 \mathrm{ml}$, kemudian dihomogenkan kemudian dicukupkan volumenya hingga $100 \mathrm{ml}$. 
Uji Efek Antiinflamasi Ekstrak Etanol Daun Sirsak Terhadap Mencit Jantan Yang Diinduksi Dengan Karagen

d. Pembuatan Suspensi Na.CMC 1\% b/v

Sebanyak 1 gram

Na.CMC dimasukan sedikit demi sedikit ke dalam $50 \mathrm{ml}$ air suling panas (suhu $70^{\circ} \mathrm{C}$ ) sambil di aduk dengan menggunakan pengaduk elektrik hingga terbentuk larutan koloidal yang homogen, kemudian dicukupkan volumenya hingga $100 \mathrm{ml}$ dengan air suling (Parrot, 1979).

e. Pembuatan

Bahan

Pembanding Suspensi

Natrium Diklofenak $\mathbf{9 , 1}$ $\mathrm{mg} / \mathrm{KgBB}$

Sebanyak 20 tablet Natrium diklofenak (setiap tablet mengandung Natrium diklofenak $50 \mathrm{mg}$ ) ditimbang kemudian dihitung bobot rata-rata, lalu digerus. Serbuk tablet Natrium diklofenak ditimbang sebanyak 66,16428 mg yang setara dengan 9,1 $\mathrm{mg} / \mathrm{KgBB}$, kemudian dimasukkan kedalam lumpang, ditambahkan larutan koloidal Na.CMC $1 \%$ sedikit demi sedikit sambil digerus hinggah omogen lalu dimasukkan kedalam labu tentukur $50 \mathrm{ml}$ dan volumenya dicukupkan sampai $50 \mathrm{ml}$.

f. Pemilihan dan

\section{Pemeliharan Hewan Uji}

Hewan uji yang digunakan dalam penelitian ini adalah mencit (Mus musculus) jantan yang sehat dengan bobot badan 20-30 gram, digunakan 15 ekor yang dibagi dalam 5 kelompok masing-masing terdiri atas 3 ekor.

g. Perlakuan

Terhadap Hewan Uji

Mencit dipuasakan selama 8 jam sebelum perlakuan kemudian ditimbang berat badannya, semua hewan uji diukur volume kakinya menggunakan

pletismometer, lalu disuntikkan karagen sebanyak $0,1 \mathrm{ml}$ secara subkutan. Hewan uji dipelihara selama 1 hari kemudian dilakukan pengukuran volume kaki hewan uji (volume awal) .Hewan uji dibagi dalam 5 kelompok, kelompok । 
Uji Efek Antiinflamasi Ekstrak Etanol Daun Sirsak Terhadap Mencit Jantan Yang Diinduksi Dengan Karagen

\begin{tabular}{|c|c|}
\hline diberilarutan koloida & mencit adalah peroral, \\
\hline INa.CMC sebagai control & selanjutnya \\
\hline negatif. Kelompok II diberi & pengukuran \\
\hline suspense & pletismometer. \\
\hline diklofenak & h. Penentuan Volume Edema \\
\hline pembanding, kelompok III & Volume edema pada \\
\hline diberi ekstrak etanol daun & telapak kaki mencit di uk \\
\hline sirsak dengan dosis 0,182 & dengan \\
\hline g/KgBB, kelompok IV diberi & mencelupkannya \\
\hline ekstrak etanol daun sirsak & pletismometer setiap selan \\
\hline dengan dosis $0,546 \mathrm{~g} / \mathrm{KgBB}$, & waktu 30 menit selama 2 \\
\hline dan kelompok $\mathrm{V}$ diberi & jam. Kemudian dilihat \\
\hline ekstrak etanol daun sirsak & inflamasi \\
\hline dengan dosis $0,91 \mathrm{~g} / \mathrm{KgBB}$. & berdasarkan kenaikan raksa \\
\hline Seluruh pemberian pada & pada pletismometer. \\
\hline
\end{tabular}

\section{HASIL PENELITIAN}

Tabel 1. Data hasil pengukuran kenaikan volume $(\mathrm{cm})$ pada pletismometer sebelum dan setelah waktu (menit) perlakuan

\begin{tabular}{|c|c|c|c|c|c|c|c|}
\hline \multirow[t]{2}{*}{ PERLAKUAN } & \multirow[t]{2}{*}{ REPLIKASI } & \multirow{2}{*}{$\begin{array}{l}\text { SEBELUM } \\
\text { PERLAKUAN }\end{array}$} & \multicolumn{5}{|c|}{$\begin{array}{c}\text { SETELAH PERLAKUAN } \\
\text { (MENIT) }\end{array}$} \\
\hline & & & 0 & 30 & 60 & 90 & 120 \\
\hline \multirow{3}{*}{ Na.CMC $1 \%$} & 1 & 1 & 1 & 2 & 2 & 2 & 2 \\
\hline & 2 & 2 & 3 & 4 & 4 & 4 & 4 \\
\hline & 3 & 1 & 2 & 3 & 3 & 3 & 3 \\
\hline \multirow{3}{*}{$\begin{array}{l}\text { Ekstrak Etanol Daun } \\
\text { Sirsak Dosis 0,182 } \\
\text { g/kgBB }\end{array}$} & 1 & 2 & 3 & 3 & 3 & 3 & 2 \\
\hline & 2 & 1 & 2 & 2 & 2 & 2 & 2 \\
\hline & 3 & 1 & 2 & 2 & 2 & 1 & 1 \\
\hline \multirow{3}{*}{$\begin{array}{l}\text { Ekstrak Etanol Daun } \\
\text { Sirsak Dosis } 0,546 \\
\text { g/kgBB }\end{array}$} & 1 & 1 & 2 & 2 & 2 & 1 & 1 \\
\hline & 2 & 1 & 3 & 3 & 3 & 3 & 2 \\
\hline & 3 & 1 & 3 & 3 & 3 & 2 & 2 \\
\hline \multirow{3}{*}{$\begin{array}{l}\text { Ekstrak Etanol Daun } \\
\text { Sirsak Dosis 0,91 g/kgBB }\end{array}$} & 1 & 1 & 2 & 2 & 1 & 1 & 1 \\
\hline & 2 & 2 & 3 & 3 & 2 & 2 & 2 \\
\hline & 3 & 1 & 2 & 3 & 2 & 2 & 1 \\
\hline \multirow{3}{*}{ NatriumDiklofenak } & 1 & 1 & 2 & 3 & 2 & 1 & 1 \\
\hline & 2 & 1 & 2 & 3 & 2 & 2 & 1 \\
\hline & 3 & 2 & 3 & 4 & 3 & 2 & 2 \\
\hline
\end{tabular}


Uji Efek Antiinflamasi Ekstrak Etanol Daun Sirsak Terhadap Mencit Jantan Yang Diinduksi Dengan Karagen

Tabel 2. Data hasil pengukuran volume $(\mathrm{ml})$ inflamasi sebelum dan setelah waktu (menit) perlakuan

\begin{tabular}{|c|c|c|c|c|c|c|c|}
\hline \multirow{2}{*}{ PERLAKUAN } & \multirow{2}{*}{ REPLIKASI } & \multirow{2}{*}{$\begin{array}{l}\text { SEBELUM } \\
\text { PERLAKUAN }\end{array}$} & \multicolumn{5}{|c|}{ SETELAH PERLAKUAN (MENIT) } \\
\hline & & & 0 & 30 & 60 & 90 & 120 \\
\hline \multirow{3}{*}{ Na.CMC $1 \%$} & 1 & 0.133 & 0.133 & 0.266 & 0.266 & 0.266 & 0.266 \\
\hline & 2 & 0.266 & 0.398 & 0.531 & 0.531 & 0.531 & 0.531 \\
\hline & 3 & 0.133 & 0.266 & 0.398 & 0.398 & 0.398 & 0.398 \\
\hline Ekstrak Etanol & 1 & 0.266 & 0.398 & 0.398 & 0.398 & 0.398 & 0.266 \\
\hline \multirow{2}{*}{$\begin{array}{l}\text { Daun Sirsak Dosis } \\
0,182 \mathrm{~g} / \mathrm{kgBB}\end{array}$} & 2 & 0.133 & 0.266 & 0.266 & 0.266 & 0.266 & 0.266 \\
\hline & 3 & 0.133 & 0.266 & 0.266 & 0.266 & 0.133 & 0.133 \\
\hline \multirow{3}{*}{$\begin{array}{l}\text { Ekstrak Etanol } \\
\text { Daun Sirsak Dosis } \\
0,546 \mathrm{~g} / \mathrm{kgBB}\end{array}$} & 1 & 0.133 & 0.266 & 0.266 & 0.266 & 0.133 & 0.133 \\
\hline & 2 & 0.133 & 0.398 & 0.398 & 0.398 & 0.398 & 0.266 \\
\hline & 3 & 0.133 & 0.398 & 0.398 & 0.398 & 0.266 & 0.266 \\
\hline \multirow{3}{*}{$\begin{array}{l}\text { Ekstrak Etanol } \\
\text { Daun Sirsak Dosis } \\
0,91 \mathrm{~g} / \mathrm{kgBB}\end{array}$} & 1 & 0.133 & 0.266 & 0.266 & 0.133 & 0.133 & 0.133 \\
\hline & 2 & 0.266 & 0.398 & 0.398 & 0.266 & 0.266 & 0.266 \\
\hline & 3 & 0.133 & 0.266 & 0.398 & 0.398 & 0.266 & 0.133 \\
\hline \multirow{3}{*}{$\begin{array}{l}\text { Natrium } \\
\text { Diklofenak }\end{array}$} & 1 & 0.133 & 0.266 & 0.398 & 0.266 & 0.133 & 0.133 \\
\hline & 2 & 0.133 & 0.266 & 0.398 & 0.266 & 0.266 & 0.133 \\
\hline & 3 & 0.266 & 0.398 & 0.531 & 0.398 & 0.266 & 0.266 \\
\hline
\end{tabular}

\section{PEMBAHASAN}

Penentuan efek Antiinflamasi ekstrak etanol daun sirsak (Annona muricata) dilakukan dengan mengukur penurunan volume edema kaki mencit (Mus musculus) jantan yang telah diinduksi dengan karagen $1 \%$. Volume edema diukur dengan menggunakan pletismometer dengan prinsip pengukuran berdasarkan hukum Archimedes yaitu benda yang dimasukkan ke dalam zat cair akan memberi gaya atau tekanan ke atas sebesar volume yang dipindahkan. Metode ini lebih sederhana, cepat, dan hasil pengukuran yang didapatkan lebih akurat dibandingkan dengan alat yang lain.

Data pengamatan menunjukkan ekstrak etanol daun sirsak (Annona muricata Linn) dengan dosis 0,182 $\mathrm{g} / \mathrm{kgBB}, 0,546 \mathrm{~g} / \mathrm{kgBB}, 0,91 \mathrm{~g} / \mathrm{kgBB}$, semua memperlihatkan efek antiinflamasi yaitu dapat menyebabkan penurunan volume bengkak atau edema dibandingkan dengan kontrol Na.CMC 1\%.

Pada tabel 2 didapatkan hasil pengukuran volume inflamasi selama 2 jam, diperoleh nilai rata-rata volume penurunan inflamasi. Data kemudian dilanjutkan untuk mengukur penurunan volume inflamasi sebelum dan setelah perlakuan (pemberian ekstrak). Hasil analisisnya menunjukkan perbedaan nyata dengan nilai 0,000 , artinya pengaruh perlakuan terhadap penurunan volume inflamasi pada mencit adalah signifikan $(P<0,005)$.

Data kemudian dianalisis kembali menggunakan ANOVA untuk menentukan perbedaan antar kelompok (dapat dilihat pada tabel 6). Dari pengamatan data tersebut 
Uji Efek Antiinflamasi Ekstrak Etanol Daun Sirsak Terhadap Mencit Jantan Yang Diinduksi Dengan Karagen

diperoleh nilai sebesar signifikan, artinya terdapat perbedaan nyata antara tiap kelompok. Karena hasil yang diperoleh signifikan, maka analisis dilanjutkan pada Post Hoc Tests dengan uji LSD untuk melihat perbedaan antar kelompok (dapat dilihat pada tabel 7). Dari analisis tersebut kelompok $\mathrm{Na}-\mathrm{CMC}$ menunjukkan perbedaan nyata (signifikan) terhadap Natrium Diklofenak, ekstrak etanol daun sirsak (Annona muricata Linn.) dosis 0,182 $\mathrm{g} / \mathrm{kgBB}$, dosis 0,546 $\mathrm{g} / \mathrm{kg} \mathrm{BB}$, dosis $0,91 \mathrm{~g} / \mathrm{kg}$ BB dengan nilai berturutturut adalah 0,001, 0,004, 0,021, 0,001 . Artinya, Na. CMC memiliki efek yang berbeda nyata dengan efek Natrium diklofenak ekstrak etanol daun sirsak (Annona muricata Linn.).

Kelompok Natrium dikolofenak menunjukkan nilai yang tidak signifikan terhadap ekstrak etanol daun sirsak (Annona muricata Linn.) dosis 0,182 $\mathrm{g} / \mathrm{kgBB}$, dosis 0,546 $\mathrm{g} / \mathrm{kgBB}$, dosis $0,91 \mathrm{~g} / \mathrm{kgBB}$ dengan nilai berturutturut adalah 0,382, 0,097, dan 1,000. Artinya efek penurunan inflamasi Natrium diklofenak memiliki efek yang sama dengan efek ekstrak etanol daun sirsak (Annona muricata Linn.)

Kelompok ekstrak etanol daun sirsak (Annona muricata Linn.) dosis $0,182 \mathrm{~g} / \mathrm{kgBB}$ menunjukkan nilai yang tidak signifikan terhadap Natrium diklofenak, ekstrak etanol daun sirsak (Annona muricata Linn.) dosis 0,546 $\mathrm{g} / \mathrm{kgBB}$, dosis 0,91 $\mathrm{g} / \mathrm{kgBB}$ dengan nilai berturut-turut adalah 0,382 , $0,382,0,382$. Begitupun juga dengan Kelompok ekstrak etanol daun sirsak (Annona muricata Linn.) dosis 0,546 $\mathrm{g} / \mathrm{kgBB}$ dan 0,91 $\mathrm{g} / \mathrm{kgBB} \quad$ juga menunjukkan nilai yang tidak signifikan dengan Natrium diklofenak dengan nilai berturut-turut $0,097,0,382,0,097$ dan $1,000,0,382,0,097$. Artinya ketiga kelompok ini memiliki efek yang tidak berbeda nyata dengan Natrium diklofenak.

Hasil analisis menunjukkan bahwa ekstrak etanol daun Sirsak (Annona muricata Linn.) dosis 0,182 $\mathrm{g} / \mathrm{kgBB}, \quad 0,546 \quad \mathrm{~g} / \mathrm{kgBB}$ dan $\quad 0,91$ $\mathrm{g} / \mathrm{kgBB}$ mempunyai potensi sebagai antiinflamasi.

\section{KESIMPULAN}

Berdasarkan hasil penelitian dapat disimpulkan bahwa :

1. Ekstrak etanol Daun Sirsak (Annona muricata Linn.)pada dosis 0,182 $\mathrm{g} / \mathrm{kgBB}, 0,546 \mathrm{~g} / \mathrm{kgBB}$ dan $0,91 \mathrm{~g} / \mathrm{kgBB}$ memiliki potensi sebagai antiinflamasi.

2. Efek penurunan volume inflamasi sudah dapat terlihat pada Dosis $0,182 \mathrm{~g} / \mathrm{kgBB}$. 
Uji Efek Antiinflamasi Ekstrak Etanol Daun Sirsak Terhadap Mencit Jantan Yang Diinduksi Dengan Karagen

\section{DAFTAR PUSTAKA}

Baratawidjaja, K.G., 2006,"Imunologi Dasar", Fakultas Kedokteran Universitas Indonesia, Jakarta.

Corwin, j.Elizabeth, 2009," Buku Saku Fatofisiolog ", Buku Kedokteran EGC, Jakarta.

Farah Bararah, vera. 2010. "Ini Dia Keistimewaan Sirsak Sebagai Obat Kanker ". (Online) (http:// health.detik.com/ read/2010/10/ 25/ 170814/ 1474420/ 763/ ini dia keistimewaan sirsak sebagai obat-kanker) diakses 27 Maret 2011

Ganiswarna, S.G., 1995,"Farmakologi dan Terapi", Edisi IV, Bagian Farmakologi Fakultas Kedokteran, Universitas Indonesia, Gaya Baru. Jakarta.

Gennaro, A.R., 1990,"Remington's Pharmaceutical Science", Eighteen Edition, Mack Publishing Company, Easton Pensylvania.

Hariana, Arif. 2007."Tumbuhan ObatdanKhasiatnya "Seri 3.PenebarSwadaya, Jakarta.

Jasin., dan Soemkari., 1992, "Zoologi Vertebrata Untuk Perguruan Tinggi”, PT. Antariksa, Surabaya.

Katzung, B.G., 2002,"Farmakologi Dasar dan Klinik”, Edisi VIII, Salemba Medika, Jakarta.

Kibbe, A.H., 2000,"Handbook of Pharmaceutical Excipient", Third Edition, American Pharmaceutical Asociation, Washington and Pharmaceutical Press.
Malole, M.B.M., dan Pramono, C.S.U., 1989."Penggunaan HewanHewan Percobaan di Laboratorium". Departemen Pendidikan dan Kebudayaan Direktorat. Jakarta.

Mycek, M.J., dan Harvey, R.A., dan Champe, P.C., 2001, "Farmakologi Ulasan Bergambar", Edisi II, Widya Medika, Jakarta.

Price, S.A, Wilson, L.M., 1995,"Patofisiologi Konsep Klinis Proses-Proses Penyakit", Buku Kedokteran EGC. Jakarta.

Pringgoutomo, S., 2002,"Buku Ajar Patologi I (umum)", Edisi I Penerbit Sagung Seto. Jakarta.

Rahima, Anik. 2011. "Menyembuhkan Kankerdengan Daun Sirsak ". Arta Pustaka, Yogyakarta.

Raina, MH. 2011. “ Ensiklopedi Tanaman Obat Untuk Kesehatan". Absolut, Yogyakarta.

Robins, S.L., Kumar, V.,1995,"Buku Ajar Patologi r', Buku Kedokteran EGC. Jakarta.

Santoso, H., B., 2008, "Ragam dan Khasiat Tanaman Obat", Agromedia Pustaka, jakarta.

Sudoyo, W.A., dkk., 2006,"IImu Penyakit Dalam", Jilid IV, Departemen IImu Penyakit Dalam Fakultas Kedokteran Universitas Indonesia, Jakarta.

Sunarjono, H. 2005. " Sirsak dan Srikaya ".Penebar Swadaya, Jakarta.

Syaifuddin, B.AC., 2000," Fungsi Sistem Tubuh Manusia", Seri 
Uji Efek Antiinflamasi Ekstrak Etanol Daun Sirsak Terhadap Mencit Jantan Yang Diinduksi Dengan Karagen

Agribisnis, Widya Medika. Jakarta.

Tan, H.T., dan Rahardja, K., 2002, "Obat-Obat Penting", Edisi V, Gramedia, Jakarta. 